\title{
The Effects of the Comprehensive Inductive Educational Approach on the Social Behaviour of Preschool Children in Kindergarten
}

Robi Kroflič ${ }^{\star 1}$ And Helena Smrtnik Vitulić ${ }^{2}$

$\approx$ The aim of the present study was to ascertain the effects of the five-month implementation of the comprehensive inductive educational approach on the social behaviour of kindergarten children. The sample consisted of 52 children in the experimental group and 48 children in the control group, aged from 2.6 to 6.0 years. The kindergarten teachers responsible for the two groups completed the Slovenian version of the Social Competence and Behaviour Evaluation questionnaire before and after the implementation of the approach. The children in the experimental group achieved higher scores than those in the control group on five of the eight basic scales of social behaviour, and on two of the three composite scales, as well as on the general result of social adaptation. It can be concluded that the implementation of the comprehensive educational approach influenced various aspects of the children's social behaviour.

Keywords: inductive educational approach, early childhood, kindergarten, social behaviour

$1 \quad{ }^{\star}$ Corresponding Author. University of Ljubljana, Faculty of Arts, Slovenia; robi.kroflic@gmail.com

2 University of Ljubljana, Faculty of Education, Slovenia 


\section{Učinki celovitega induktivnega vzgojnega pristopa na socialno vedenje predšolskih otrok v vrtcu}

Robi Kroflič ${ }^{\star}$ in Helena Smrtnik Vitulić

$\propto$ Namen prispevka je prikazati učinke petmesečnega uvajanja celovitega induktivnega vzgojnega pristopa na socialno vedenje vrtčevskih otrok. Vzorec je zajemal 52 otrok v eksperimentalni skupini in 48 otrok v kontrolni skupini, starih od 2,6 leta do 6 let. Predšolske vzgojiteljice, zadolžene za obe skupini otrok, so izpolnjevale slovensko različico Vprašalnika o socialnem vedenju otrok pred uvedbo celovitega induktivnega vzgojnega pristopa in po njej. Otroci v eksperimentalni skupini so dosegli boljše rezultate kot otroci v kontrolni skupini na petih od osmih osnovnih lestvic, nadalje na dveh od treh sestavljenih lestvic pa tudi v skupnem rezultatu socialne prilagojenosti. Sklenemo lahko, da je implementacija celovitega induktivnega vzgojnega pristopa pozitivno vplivala na različne vidike socialnega vedenja otrok.

Ključne besede: induktivni vzgojni pristop, zgodnje otroštvo, vrtec, socialno vedenje 


\section{Introduction}

Recently, there has been increasing interest in the emotional, social and affective dimensions in examining moral development and how it is influenced by education, whereas in the so-called pre-Kohlbergian period (Kristjansson, 2004) these dimensions were notably neglected. In the philosophy of education, there is increased awareness of the importance of relational ethics, particularly the ethics of care and Levinas' ethics of "face-to-face" encounter (Dahlberg \& Moss, 2005; Kroflič, 2010). In his ethics, Levinas highlights responsibility towards other human beings and suggests that contextualised reasoning should replace submission to universal norms, as well as emphasising a respectful attitude towards difference (Levinas, 2006; Moss, 2008). A similar trend can be observed in numerous psychological studies (Eisenberg, Losoja, \& Guthrie, 1997; Eisenberg et al., 2001; Eisenberg, Cumberland, Guthrie, Murphy, \& Shepard, 2005; Horvat \& Zupančič, 2010) underlining the importance of the child's encounter with the real other person, leading to the emergence of complex prosocial emotions, which represent the core foundation of children's social competence. The latter is closely linked to the developing ability of social perspective-taking, representing the individual's cognitive and emotional ability to understand other people's emotions, motives and intentions (Eisenberg \& Mussen, 1997). Children's social competence also includes effective emotional regulation. Emotionally well-regulated people are capable of managing their emotions in a flexible and socially acceptable way. "Optimal emotion regulation is not a developmental task to be mastered at a certain age [...], but rather a 'moving target' that is continually sensitive to changing goals and contexts" (Diamond \& Aspinwall, 2003, p. 149).

These findings have led to the construction of three crucial components of the main educational approaches: (1) the realisation that children are more cognitively and socially sensitive than they were seen to be in traditional stage theories of moral, cognitive and socio-cognitive development (Moss, Dillon, \& Statham, 2010); (2) the recognition that prosocial emotions such as emphatic guilt (a child's ability not only to empathise with the victim's distress but also to be aware of his/her responsibility for it (Krevans \& Gibbs, 1996), which is not a result of the internalised moral norms of the child's social environment, typical of so-called anxiety-based and inhibitory psychoanalytic guilt) and compassion, which represent the main basis of prosocial sensibility, arise in children even before they are fully capable of competent moral reasoning (Kristjansson, 2004); and (3) the realisation that moral consciousness is always linked to our basic responsibility towards other human beings and their well-being 
(Levinas, 2006). When responsibility is perceived in this way, it clearly cannot be achieved through discipline as a form of achieving submission to the established social norms and values, but rather through encouraging the child to enter various social relations in the social arena in a respectful manner. Secondly, educational activities should not be reduced to inductive discipline practice, but should also include a variety of activities that promote positive social experiences. Today, there are various educational concepts coming to the fore that are based on these postulates; two prominent examples worth mentioning are relational pedagogy (Bingham \& Sidorkin, 2004) and the pedagogy of listening (Rinaldi, 2006). Similar starting points provide the basis of the comprehensive inductive educational approach that we put forth in the present paper.

\section{Approaches to inductive discipline}

Hoffman (2000) was the first to report endeavours to form an inductive approach to discipline in the context of family upbringing. According to the inductive approach to discipline, when a child misbehaves, one should clearly state disapproval of the behaviour. This should then be followed by drawing attention to the distress of the person harmed by the child's actions and highlighting the child's role in causing this distress, thus prompting the emergence of empathic guilt in the child (Hoffman, 2000). Such an approach encourages the development of prosocial emotions in the wrongdoer, and the child is much more likely to feel the need and willingness to correct his/her "wrong".

Since the 1990s, various authors have echoed Hoffman's model of inductive discipline. Krevans and Gibbs (1996) reported findings about the inductive approach to discipline successfully encouraging children's prosocial behaviour. As one of the challenges of inductive discipline, however, the authors stated that better distinctions need to be found between empathy-based and psychoanalytic guilt, as well as between love withdrawal, other-oriented induction and parental disappointment. On the other hand, Eisenberg et al. (1997) stated the advantages of the inductive discipline approach, emphasising that using the inductive educational method it is possible to encourage the development of perspective-taking in children, to teach children how to take responsibility for their actions, to develop internal motivation and to promote prosocial behaviour.

\section{Theoretical premises of the "comprehensive inductive educational approach" (CIEA) and its application in kindergarten}

The principal aim of moral education is, in our view, captured in Levinas's provocative claim that morals are not primarily concerned with the 
individual's attitude towards social rules and ethical principles, but rather with a respectful attitude towards other human beings and the environment, and towards building a meaningful existence (Kroflič, 2007). This means that, as ethically responsible beings, we have a responsibility to direct our intentions by taking into account the well-being of other people and the environment, as opposed to merely subjecting our actions to social norms.

With regard to the question of shaping a stimulating environment, the CIEA is built on the finding that children's primary prosocial skills develop through their interactions with significant others (adults) and with their peers, i.e., through genuine relationships characterised by love and friendship. In a stimulating environment with emotionally positive adults and children, the child's ability to form such relationships develops already in earliest childhood (Marjanovič Umek \& Fekonja Peklaj, 2008). In addition to inductive discipline enabling systematic mediation in the case of conflicts, the CIEA applied in kindergarten as an "elaboration" of inductive approaches also comprised other educational activities, such as encouraging prosocial activity (mutual help, for example), minimising fear of difference, promoting team work, and finally, one of the most efficient activities, education through art (Kroflič, 2011).

Based on the theoretical premises described above and on an array of educational activities, we determined the basic structure of the comprehensive inductive model of encouraging prosocial and moral development:

1. even though ethical consciousness demands complex cognitive capacities, children are capable of entering relations characterised by love and friendship already in early childhood, enabling them to develop relational response-ability and normative agency for prosocial activities in a truly genuine way;

2. given that in personally engaged relations one may also sometimes harm a person, the second step is developing a sense of respect towards specific persons or activities, and towards action;

3. the last step of moral education is to become aware of ethical principles and humanistic demands, especially concerning human rights and ecological values, and to learn how to use them as a basis for democratic negotiation in cases of interpersonal conflicts (Kroflič, 2007, 2011).

These guidelines were used by kindergarten teachers to plan their activities when working with children. In order to encourage the development of relational response-ability and normative agency, the teacher should introduce an array of activities that encourage various routes of communication between children and their peers, as well as between children and adults, and that lead to 
closer personal attachment relationships. A sense of respect towards the feelings of others develops as the child engages in experimentation and begins testing, in various ways, how adults and peers respond to his/her actions. When children's actions lead to another person's negative emotional response, children often try to avoid being confronted with the consequences of their own actions. In this case, the inductive role means that the teacher should, first of all, prevent children from avoiding the unpleasant feeling that comes from facing the other person's emotional distress caused by them. Secondly, the adult should refrain from explaining to the child why a certain action is inappropriate. In this way, the teacher enables children to grasp the connection between "cause" and "effect" on their own, and to themselves realise what they have done wrong. Insisting that children take "responsibility" for the consequences of their actions does not mean that one should issue disciplinary warnings (statements like "you shouldn't do that"), but that children should face the emotional distress of the other person, which frequently leads to their own feelings of hurt, empathic guilt and compassion, as well as to the cognitive processing of the event. If children are enabled to do this, they will try to make the wrong right in order to end their own distress, while at the same time strengthening their image of what (dis)respectful relationships look like. It is only in the third step of education that generalisations are used in the form of understanding the meaning of specific values and ethical principles, as well as bringing insight into the fact that the easiest way to regulate life in a community or an institution is through rules agreed upon in advance. Research focusing on the understanding of rules that prevent moral conflicts demonstrates that preschool children are already capable of understanding such rules and using them in choosing their actions (Durkin, 1995).

The present research was guided by the aspiration to develop a CIEA that would encourage children's prosocial and moral development, and that could be used in the everyday institutional practice of kindergartens as well as in primary education. We gathered the outcomes of the five-month implementation of the CIEA regarding various aspects of kindergarten children's social behaviour. Specifically, we sought to determine whether the CIEA (through fostering the development of empathic guilt) influences the promotion of prosocial behaviour and has a positive effect on the reduced internalisation of behaviour problems (less depression, anxiety, isolation and dependency), as previous findings regarding the use of inductive educational discipline in the family context indicate the need for better distinctions between empathy-based and psychoanalytic guilt, as well as between love withdrawal, other-oriented induction and parental disappointment (Krevans \& Gibbs, 1996). 


\section{Method}

\section{Research design and procedure}

In order to identify the effects of the CIEA on conventional education, the study employed a quasi-experimental "equivalent Control Group with PostTest” (Berg \& Latin, 1994, in Hossain, Tarmizi, Aziz, \& Nordin, 2013, p. 45). Prior to the experiment treatment, the two groups involved should be similar in terms of the measured characteristics. Consequently, if one group receives experimental treatment and post-treatment group differences appear at a dependent variable, these differences may be understood as a result of the treatment (Leedy \& Ormroad, 2002, in Hossain et al., 2013).

Prior to conducting the study, the kindergarten management, kindergarten teachers and parents involved agreed to the implementation of the CIEA and to obtaining data about the selected children by signing a written agreement. After the pre-test (the kindergarten teachers completed a questionnaire about each child's social behaviour) in the control group (CG) and the experimental group (EG), we commenced the implementation of the CIEA in the EG. The experimental kindergarten teachers who were assigned to the implementation group were properly trained, attending three lectures with discussions, where they were acquainted with the main theoretical framework of the educational approach and with their active role in promoting children's prosocial and moral behaviour. The main purpose of this training course was to enable teachers to understand the basic ideas of the CIEA model of promoting the prosocial and moral development of preschool children, and to help teachers to distinguish the CIEA from the classic fostering of psychoanalytic guilt as a method of emotional conditioning with love withdrawal and as a means of promoting the child's ability to adapt to the social order of the kindergarten environment. The implementation of the CIEA in the group of kindergarten children took place from mid-January to mid-June 2010. Once a month, the experimental kindergarten teachers evaluated examples of the implementation of the CIEA with three pedagogues who participated in the project and were trained to use this method.

The post-test of children's social behaviour was administered to both the EG and the CG; the kindergarten teachers answered the same questionnaire of social behaviour as in the pre-test for each child participating in the study. The second measurement took place at the end of June 2010.

\section{Participants}

From a total of 114 children in the chosen kindergarten unit in Ljubljana, where the children participated in the comprehensive educational approach, 
52 children (60\% girls) were selected for the EG. The selection of children was done by sampling according to alphabetical order and selecting every other girl and every other boy from each group following the alphabetical order of their surnames. The lower age limit (2.5 years) was also taken into account in the sampling procedure, as the questionnaire chosen is designed for evaluating children older than 2.5 years. The same sampling method was used to obtain a comparable sample of children for the CG at another unit of the kindergarten, where children were not taught according to the principles of the comprehensive induction approach. In the CG, 48 children ( $55 \%$ girls) were selected to participate in the research.

Eight kindergarten teachers completed questionnaires for each of the 52 selected children from the EG, while nine kindergarten teachers from the CG completed questionnaires for each of the 48 selected children. Measurement was repeated in both groups after five months. At the time of the first measurement, the age of the children from the EG ranged from 3.4 years to 6.0 years ( $M$ $=4.8$ years, $S D=0.2)$, while the age of children from the CG ranged from 2.4 years to 6.0 years $(M=4.9$ years, $S D=0.3)$.

\section{Instrument}

The SV-O questionnaire (LaFreniere, Dumas, Zupančič, Gril, \& Kavčič, 2001), the Slovenian version of the Social Competence Behaviour Evaluation questionnaire (SCBE, LaFreniere \& Dumas, 1995, in LaFreniere et al., 2001), with norms for Slovenian children, was used to evaluate social behaviour. The questionnaire is primarily designed for kindergarten teachers and teachers in the first year of primary school to evaluate the behaviour of individual children in the educational institution. The SV-O questionnaire consists of 80 statements about the child's behaviour rated on a 6-point scale (from $1=$ the behaviour never or almost never occurs to 6 = the behaviour almost always occurs). The items are then combined into eight basic scales. The first three basic scales (Joyful-Depressive, Secure-Anxious and Tolerant-Angry) describe the emotional adaptation of the child (general mood, feelings of safety within a group, and coping with situations), the next three basic scales (Integrated-Isolated, Calm-Aggressive and Prosocial-Egotistical) define the main characteristics of the child's social interaction with peers (the level of the child's integration into the peer group, aggressive behaviour towards peers, and expressed sensitivity to the needs and wishes of others), and the last two basic scales (Cooperative-Oppositional and Autonomous-Dependent) measure the child's interaction with adults (the level of the child's cooperation in interactions with the kindergarten teacher and the child's independence from the teacher in the group). 
The basic scales combine into four composite scales, i.e., Social Competence (the positive poles of all eight basic scales), Internalising Problems (the negative poles of four basic scales: Depressed, Anxious, Isolated and Dependent), Externalising Problems (the negative poles of the other four basic scales: Angry, Aggressive, Egotistical and Oppositional), and General Adaptation, which represents the general score for the 80 items. A higher result ( $T$ value) on each individual and composite scale indicates a higher level of the child's socially competent behaviour. According to the norms in the manual, the range between $38 T$ and $62 T$ represents an "average result" (80\% of the normative population), values higher than $63 T$ represent an "above average result" (10\% of the normative population) and values lower than $37 T$ indicate a "below average result" (10\% of the normative population).

The questionnaire has a sufficiently high internal reliability ( $\alpha$ 's coefficients ranging from 0.69 to 0.89 ; La Freniere et al., 2001), as well as internal reliability of composite scales ( $\alpha$ 's coefficients ranging from 0.85 to 0.95 ) and testretest reliability (coefficients ranging from 0.74 to o.89) (Zupančič \& Kavčič, 2007). In the present study, the coefficients of internal reliability for the EG and the CG at both times of measurements ranged from 0.85 to 0.93 for basic scales, and from 0.71 to 0.95 for composite scales.

\section{Data analysis}

In order to determine the similarity between the EG and the CG before the implementation of comprehensive induction, $t$-tests for independent samples were used, while $t$-tests for dependent samples were used to compare social behaviour scores in the CG group before and after the implementation of comprehensive induction. In both cases, t-tests (for dependent and independent samples) were used after checking for normality of distribution and homogeneity of variances (Levene's tests were greater than 0.05). The interaction between the social behaviour scores of the EG and the CG and time (before and after implementing the CIEA) was also checked. After confirming the normality of distribution, the homogeneity of variances of the groups (Levene's tests were greater than 0.05) and the homogeneity of intercorrelations, mixed between subject ANOVA design, was verified.

\section{Results}

The study was conducted in order to determine the effect of the implementation of the CIEA on children's social behaviour in kindergarten. The results were analysed both on the level of basic and composite scales of social 
behaviour. The average values and standard deviations of social behaviour for the EG and the CG before and after the CIEA can be found in Table 1.

Table 1. Descriptive statistics of SV-O scores (T-values) for the experimental and control groups before and after the implementation of comprehensive induction

\begin{tabular}{lccccccccc}
\hline & \multicolumn{2}{c}{$\mathrm{EG}_{1}(\mathrm{n}=52)$} & \multicolumn{2}{c}{$\mathrm{CG}_{1}(\mathrm{n}=48)$} & \multicolumn{2}{c}{$\mathrm{EG}_{2}(\mathrm{n}=52)$} & \multicolumn{2}{c}{$\mathrm{CG}_{2}(\mathrm{n}=48)$} \\
& $\mathrm{M}$ & $\mathrm{SD}$ & $\mathrm{M}$ & $\mathrm{SD}$ & $\mathrm{M}$ & $\mathrm{SD}$ & $\mathrm{M}$ & $\mathrm{SD}$ \\
\hline Basic scales: & & & & & & & & \\
Joyful - Depressed & 54.10 & 8.89 & 50.94 & 8.65 & 55.00 & 10.13 & 48.10 & 7.14 \\
Secure - Anxious & 54.40 & 8.19 & 50.78 & 9.29 & 54.96 & 9.26 & 48.42 & 8.03 \\
Tolerant - Angry & 49.02 & 9.90 & 51.49 & 10.25 & 52.54 & 11.20 & 50.36 & 7.55 \\
Integrated - Isolated & 52.75 & 8.11 & 50.67 & 9.55 & 55.46 & 9.70 & 50.88 & 9.53 \\
Calm - Aggressive & 47.50 & 8.47 & 49.59 & 9.04 & 51.17 & 9.61 & 46.82 & 7.39 \\
Prosocial - Egotistical & 50.88 & 8.63 & 53.18 & 10.77 & 52.63 & 10.47 & 51.53 & 7.49 \\
Cooperative - Oppositional & 47.98 & 8.45 & 48.98 & 9.46 & 51.29 & 10.37 & 46.86 & 8.62 \\
Autonomous - Dependent & 50.88 & 7.64 & 50.02 & 10.57 & 54.54 & 9.80 & 46.27 & 7.97 \\
\hline Composite scales: & & & & & & & & \\
Social Competence & 50.71 & 8.01 & 49.24 & 11.23 & 54.81 & 10.79 & 46.76 & 8.69 \\
Internalising Problems & 53.71 & 7.74 & 52.35 & 8.59 & 57.13 & 10.66 & 49.88 & 7.79 \\
Externalising Problems & 49.46 & 11.08 & 53.41 & 10.26 & 50.67 & 10.85 & 51.65 & 9.09 \\
General Adaptation & 51.90 & 8.33 & 51.80 & 10.34 & 57.69 & 11.20 & 51.14 & 8.73 \\
\hline
\end{tabular}

Note: $\mathrm{CG}_{1}=$ control group at the time of first measurement, $E G_{1}=$ experimental group at the time of first measurement, $\mathrm{CG}_{2}=$ control group at the time of second measurement, $\mathrm{EG}_{2}=$ experimental group at the time of second measurement.

\section{A comparison of the social behaviour scores of the EG and the CG before the implementation of comprehensive induction}

The results reveal that the differences between the pre-test mean score of the EG and the CG were not significant at the beginning of the study on seven of the eight basic scales, on all four composite scales, and on the overall result (General Adaptation scale). A significant difference between the groups was identified only for the Anxious-Secure basic scale $(t(2,48)=2.07, p=0.04)$, where the EG achieved higher average scores than the CG (see Table 1).

\section{A comparison of social behaviour scores within the CG}

The results of the two measurements of the CG were similar regarding the mean scores on the level of the majority of basic and composite scales; significant differences between the mean scores were found only on two of the 
eight basic scales of social behaviour: Calm-Aggressive $(t(2,48)=2.15, p=0.04)$ and Autonomous-Dependent $(t(2,48)=2.39, p=0.02)$. It is interesting that the mean scores of these two scales were lower at the second time of measurement compared to first time (see Table 1).

\section{Interaction between the social behaviour scores of the EG and the CG and time}

The results of the mixed between-subject analysis of variances indicated statistically significant interactions between the social behaviour scores of the EG and the CG and time on five of the eight basic subscales of social behaviour, i.e., Joyful-Depressed (Wilks' Lambda $=.97, F=(1,99)=3.93, p<.05$, partial $\eta^{2}=.04$ ), Tolerant-Angry (Wilks' Lambda $=.95, F=(1,99)=5.51, p<.05$, partial $\left.\eta^{2}=.05\right)$, Calm-Aggressive (Wilks' Lambda $=.92, F=(1,99)=14.17, p<.01$, partial $\eta^{2}=.13$ ), Cooperative-Oppositional (Wilks' Lambda $=.88, F=(1,99)=8.92$, $p<.01$, partial $\eta^{2}=.08$ ), and Autonomous-Dependent (Wilks' Lambda $=.89$, $F=(1,99)=13.78, p<.01$, partial $\left.\eta^{2}=.12\right)$. The children from the EG achieved higher scores on the aforementioned basic scales than the children from the CG after the implementation of comprehensive induction in the EG (see Table 1).

The results of the mixed between-subject analysis of variances (interactions between social behaviour scores in groups and time) and the mean scores for the EG and the CG in both times (Table 1) also show that the EG achieved significantly higher scores than the CG on two of the three composite scales of social behaviour, i.e., Social Competence (Wilks' Lambda $=.89, F=(1,99)=$ 12.67, $p<.01$, partial $\eta^{2}=.11$ ) and Internalising Problems (Wilks' Lambda $=.92$, $F=(1,99)=8.37, p<.01$, partial $\left.\eta^{2}=.08\right)$. A significant difference between the two groups in time was also identified for General Adaptation, which represents the general score of the questionnaire (Wilks' Lambda $=.93, F=(1,99)=$ 7.31, $p<.01$, partial $\eta^{2}=.07$ ).

After the implementation of comprehensive induction in the EG, the children from the EG achieved higher scores on the aforementioned composite scales than the children from the CG (see Table 1). According to Cohen (1988), ${ }^{3}$ partial eta squared indicates a small to medium effect size in change in the social behaviour scores (for basic and composite scales) for the EG and the CG and time.

3 Cohen (1988) suggested that values between $\eta^{2}=.01-.05$ indicate a small effect, between $\eta^{2}=.06-.13$ indicate a medium effect, and $\eta^{2} \geq .14$ indicate a large effect. 


\section{Discussion}

The results of our study testify to the effectiveness of comprehensive induction regarding various aspects of kindergarten children's social behaviour. The results of social behaviour at the pretreatment stage were almost equivalent for the EG and the CG, and were average results compared to the norms. The only difference between the groups was found for the Anxious-Secure basic scale, where the EG achieved higher average scores than the CG. Furthermore, comparison of the CG results within a five-month interval showed almost no differences, except for an elevated level of aggressive behaviour in the group and more dependent behaviour towards the kindergarten teacher. In the CG, it may be possible that some unknown moderator variables were responsible for exerting influence on the children's more aggressive and dependent behaviour at the second time of measurement. Given that the CG achieved significantly lower scores on the Calm-Aggressive and Autonomous-Dependent scales at the second time of measurement compared to the first time, this may contribute in part to the differences between the EG and the CG on the AnxiousSecure scale.

As can be seen from the descriptive statistics for the EG and the CG in Table 1, $T$ values on the basic and composite scales before and after the implementation of comprehensive induction range between $46 \mathrm{~T}$ and $58 \mathrm{~T}$. According to the norms listed in the manual (LaFreniere et al., 2001), this represents an "average result" (a range encompassing $80 \%$ of children's SV-O results). The evaluation of children's general adaptation (overall score), however, was found to be significantly higher after the implementation of comprehensive induction (58T), the result being relatively close to $63 \mathrm{~T}$, a marker for a level of social adaptation that is well above average (only $10 \%$ of the normative population have a result higher than ${ }_{63} T$ ). It can therefore be assumed that the implementation of the CIEA contributed to the relatively high social adaptation of the children.

Following the five-month implementation of the CIEA, the children in the EG (in comparison to the CG) achieved higher results on five of the eight basic scales of social behaviour. The study demonstrated that the CIEA had a moderate effect on aggressive behaviour towards peers, which became less frequent. The effect of the CIEA was also significant (moderately high) regarding the children's cooperative and autonomous behaviour in interactions with the kindergarten teachers, which became more frequent after five months of the project. However, the effect of the CIEA was minimal regarding the general mood and coping with situations within a group, with children becoming more joyful and tolerant. 
On the level of the composite scales, the results similarly showed some improvement in social behaviour in the EG after five months of implementation of the CIEA. A medium effect of the introduction of the CIEA was observed regarding children's social competence (in general, children expressed more joy, security, tolerance, integration with others, calmness, prosocial behaviour, cooperativeness, and autonomy towards kindergarten teachers). The results also indicated a medium effect on the occurrence of internalising problems as a response to frustration (in general, less depression, anxiety, isolation and dependent behaviour in interactions with the kindergarten teacher), and an overall higher result of the questionnaire (General Adaptation scale) after five months.

How can these results be explained? With regular use of the CIEA, we can encourage children to become more cognitively and socially sensitive, with more (pro)social emotions towards others and with greater awareness of how to take responsibility for their actions, which may encourage children's social behaviour. This may account for why, after the implementation of the CIEA, the children in our research became more socially competent (i.e., more tolerant within a group and displaying less aggressive behaviour towards peers), with fewer of them internalising problems as a response to frustration (i.e., more responsible and autonomous in interactions with kindergarten teachers), and why they expressed more joy, contributing overall to a relatively high general social adaptation.

In view of earlier findings regarding the use of the inductive educational approach in the family context (Krevans \& Gibbs, 1996), in the present research it was specifically expected that the CIEA would promote children's prosocial behaviour. However, the study did not confirm significant differences on the Prosocial-Egotistical basic scale between the EG and the CG in time. This result could be explained by the fact that the questionnaire is used to assess prosocial behaviour in the broader sense of the word. In addition to helping and caring about other people's well-being, which generally define prosocial behaviour (e.g., Eisenberg et al., 2005), items in the questionnaire also include statements such as engaging in group activities, expressing a certain degree of competitiveness, and (dis)satisfaction when the kindergarten teacher attends to other children.

There is, however, another important difference between the results of the present study and the research by Krevans and Gibbs on parents' use of inductive discipline. Relative to previous findings (Krevans \& Gibbs, 1996), the results of our research indicate that the CIEA has less effect on internalising children's problems as a response to frustration. Given that both the inductive discipline approach and the CIEA are connected with fostering children's feeling of guilt, which can have a negative effect in terms of increasing the internalisation of 
problems, this finding indirectly confirms the successful solution to theoretical and practical problems stressed in the study by Krevans and Gibbs, i.e., to better describe the difference between emphatic and psychoanalytic guilt.

Since the effects of the CIEA on some areas of social behaviour in the kindergarten group were low to medium, it is important to emphasise that the effect of the CIEA was only measured over a five-month period, which may be too short for major changes in social behaviour to occur.

In the research, children's social behaviour was evaluated by kindergarten teachers. Relevant data on children's social behaviour can be obtained by reports by others who know the children well and who interact with them daily in specific contexts; therefore, kindergarten teachers are certainly in a position to assess the social behaviour of children, as they know them relatively well. However, the evaluations of others are always subjectively biased (Smrtnik Vitulić \& Zupančič, 2009), as different teachers may have different criteria when assessing a child's social behaviour. In the present study, this subjectivity may be even more marked, as the kindergarten teachers were simultaneously implementing the CIEA and monitoring its results. As such, teachers might be more motivated to demonstrate the positive results of the CIEA approach than other assessors not participating in the project.

\section{Conclusions}

The results suggest that by implementing the CIEA children were encouraged to express their positive feelings in a constructive manner and to improve some aspects of relations with their peers and with their kindergarten teachers. After the five-month implementation of the comprehensive induction educational approach, the children became more socially competent, with less internalisation of problems as a response to frustration, and with increased general social adaptability.

The main strength of the present study lies in the systematic measurement of the effects of the CIEA in the kindergarten context over a relatively long time interval of five months. On the other hand, among the weaknesses of the research we have already mentioned that the CIEA was implemented in a single kindergarten, and that the children's social behaviour was evaluated by kindergarten teachers who simultaneously implemented the approach. In future studies, the information about children's social development could be gathered not only through teachers' assessment, but also through interviews with the children themselves. Furthermore, children describing photos or situations with social content could be used to determine their social development. 
Future research could examine the effects of this educational approach in the family context, where children's social behaviour could be evaluated by their parents. Other factors that may influence social development could also be included in the study, such as the teacher's relationship with the children. Besides the short-term effects of the comprehensive induction approach, further research could also ascertain whether this approach may have any long-term effects on the kindergarten teacher's activities, thus promoting further positive effects both on the (pro)social and the moral development of preschool children.

Since the elaboration of the CIEA as an effective comprehensive model of fostering prosocial and moral development is based on some complex theoretical ideas (the relational model of the development of responsibility, the distinction between emphatic and psychoanalytical guilt, the distinction between an assertive, permissive and inductive style of moral education, etc.), further evaluation of its value should be based on different methodological tools. The SV-O questionnaire used in the present study enabled us to demonstrate the basic positive effects of the CIEA on children's social behaviour, but it is insufficient for providing exact evidence of the different developmental processes fostered by this new educational approach. According to the results of the present study, however, we can conclude that this educational approach can be used for the promotion of social behaviour in kindergartens.

\section{References}

Bingham, C., \& Sidorkin, A. M. (Eds.) (2004). No education without relation: Counterpoints studies in the postmodern theory of education (Vol. 259). New York, Bern, Berlin, Brussels, Frankfurt am Main,

Oxford, Vienna: Peter Lang.

Cohen, J. (1988). Statistical power analysis for the behavioral sciences ( $2^{\text {nd }}$ ed.). New Jersey: Lawrence

Erlbaum.

Dahlberg, G., \& Moss, P. (2005). Ethics and Politics in Early Childhood Education. London: Routledge. Diamond, L. M., \& Aspinwall, L. G. (2003). Emotion regulation across the life span: An integrative perspective emphasizing self-regulation, positive affect, and dyadic process. Motivation and Emotion, $27(2), 125-156$.

Durkin, K. (1995). Development social psychology from infancy to old age. Cambridge, Massachusetts, Oxford: Blackwell Publishers Inc.

Eisenberg, N., \& Mussen, P. H. (1997). The roots of prosocial behaviour in children. United Kingdom: Cambridge University Press.

Eisenberg, N., Cumberland, A., Guthrie, I. K., Murphy, B. C., \& Shepard, S. A. (2005). Age changes in prosocial responding and moral reasoning in adolescence and early adulthood. Journal of Research on Adolescence, 15(3), 235-26o. 
Eisenberg, N., Cumberland, A., Spinrad, T. L., Fabes, R. A., Shepard, S. A., Reiser, M., et al. (2001). The relations of regulation and emotionality to children's externalizing and internalizing problem behavior. Child Development, $72(4), 1112-1134$.

Eisenberg, N., Losoja, S., \& Guthrie, I. K. (1997) Social cognition and prosocial development. In S. Hala (Ed.), The development of social cognition (pp. 329-354). United Kingdom: Psychology Press. Hoffman, M. L. (2000). Empathy and moral development: implications for caring and justice. Cambridge: Cambridge University Press.

Horvat, M., \& Zupančič, M. (2010). Osebnostne poteze kot napovedniki socialnega vedenja pri prvošolcih [Personality traits as predictors of children's social adjustment to school entry]. Psihološka obzorja [Horizons of Psychology], 19(4), 111-132.

Hossain, A., Tarmizi, R. A., Aziz, Z., \& Nordin, N. (2013). Group learning effect and gender differences in mathematical performance. Croatian Journal of Education, 15(2), 41-67.

Krevans, J., \& Gibbs, J. C. (1996). Parents' use of inductive discipline: Relation to children's empathy and prosocial behavior. Child Development, 67(6), 3263-3277.

Kristjànsson, K. (2004). Empathy, sympathy, justice and the child. Journal of Moral Education, 33(3), 291-305.

Kroflič, R. (Ed.) (2010). Kulturno žlahtenje najmlajših: razvoj identitete otrok v prostoru in času preko raznovrstnih umetniških dejavnosti [Cultural enrichment of the youngest children]. Ljubljana: Vrtec Vodmat.

Kroflič, R. (2007). Vzgoja za odgovornost onkraj razsvetljenske paradigme: od razvoja odgovorazmožnosti k spoštljivemu odnosu in razvoju etične zavesti [Education for responsibility beyond the enlightenment paradigm: From the development of response-ability to a respectful attitude and development of ethical awareness]. Sodobna pedagogika [Journal of Contemporary Educational Studies], 56(3), 56-71.

Kroflič, R. (2010). Etična in politična dimenzija projekta Reggio Emilia [The ethical and political dimension of the Reggio Emilia project]. In T. Devjak, M. Batistič-Zorec, J. Vogrinc, D. Skubic, \& S. Berčnik (Eds.), Pedagoški koncept Reggio Emilia in kurikulum za vrtce: podobnosti v različnosti [The educational concept of Reggio Emilia and the kindergarten curriculum: Similarity in diversity] (pp. 11-66). Ljubljana: Faculty of Education.

Kroflič, R. (2011). The role of artistic experiences in the comprehensive inductive educational approach. Pastoral Care in Education: An International Journal of Personal, Social and Emotional Development, 3o(3), 263-280.

LaFreniere, P. J., Dumas, J. E., Zupančič, M., Gril, A., \& Kavčič, T. (2001). Vprašalnik o socialnem vedenju otrok, SV-O priročnik [A questionnaire about children's social behaviour, SV-O manual]. Ljubljana: Center za psihodiagnostična sredstva.

Levinas, E. (2006). Entre nous. London, New York: Continuum. Marjanovič Umek, L., \& Fekonja Peklaj, U. (2008). Sodoben vrtec: možnosti za otrokov razvoj in zgodnje učenje [The modern kindergarten: Opportunities for child development and early learning]. Ljubljana: ZIFF. 
Moss, P. (2008). Toward a new public education: Making globalization work for us all. Child development perspectives, 2(2), 114-119.

Moss, P., Dillon, J., \& Statham, J. (2010). 'The child in need' and 'the rich child': discourses, constructions and practice. Critical Social Policy, 20(2), 233-254.

Rinaldi, C. (2006). In dialogue with Reggio Emilia: Listening, researching and learning. London \& New York: Routledge.

Smrtnik Vitulić, H., \& Zupančič, M. (2009). Ujemanje med različnimi skupinami ocenjevalcev mladostnikove osebnosti [Agreement between different groups of informants reporting on adolescents' personality]. Didactica Slovenica, 24(3-4), 87-103.

Zupančič, M., \& Kavčič, T. (2007). Otroci od vrtca do šole: razvoj osebnosti in socialnega vedenja ter učna uspešnost prvošolcev [Children from kindergarten to school: The development of personality and social behaviour and the academic achievement of first-graders]. Ljubljana: ZIFF.

\section{Biographical note}

Robi Kroflič, $\mathrm{PhD}$, is a full time professor of theory of education and general pedagogy at the Department for pedagogy and andragogy, Faculty of Arts, University of Ljubljana, Slovenia. He is a lecturer of Theory of Education, Pedagogical Approaches to Education of Students with Special Needs, Theories of Emotional and Behavioral Difficulties and Planning of Moral and Character Education in Public Schools on the under-graduate and post-graduate level. Until now, he also had invited lectures at the universities in Gröningen (The Netherlands) and Klagenfurt (Austria). His basic fields of investigation are: theory of authority and pedagogical eros, moral education, aesthetic education and identity development, postmodern concepts of education, contemporary approaches on pre-school education.

Personal web-side: http://www2.arnes.si/ rkrofl1/bibliografija_eng.html

Helena Smrtnik Vitulić, PhD, is an Assistant Professor of developmental psychology in the Department of Education Studies at the Faculty of Education in Ljubljana, Slovenia. Her current research interests include emotions, personality and academic achievement in childhood, adolescence and in pedagogic students - future human-relations professionals who will work with various groups of people in the educational context. She has presented her work in international conferences and has published in several scientific journals. E-mail address: helena.smrtnik-vitulic@guest.arnes.si 